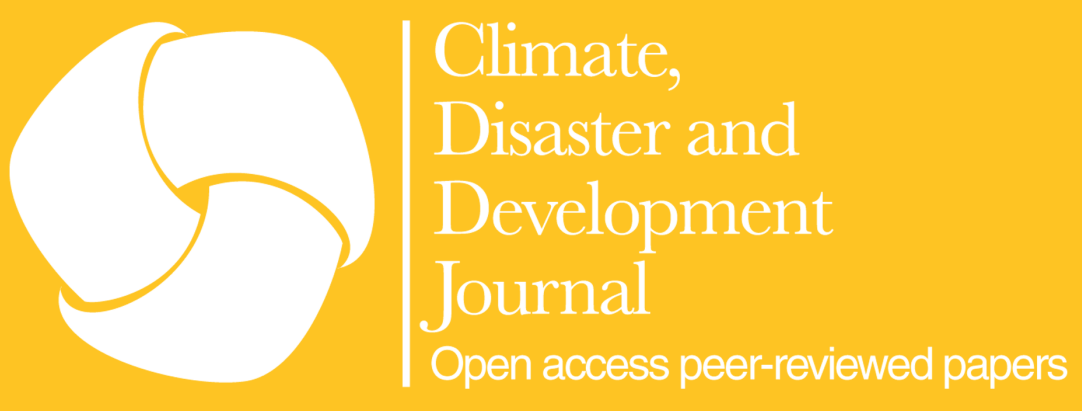

\title{
Tourism Industry Financing of Climate Change Adaptation: Exploring the Potential in Small Island Developing States
}

\author{
Janto S. Hess ${ }^{1,2} \cdot$ Ilan Kelman ${ }^{1,3,4}$ \\ ${ }^{1}$ Institute for Risk and Disaster Reduction at University College London \\ ${ }^{2}$ Earth System Governance Project \\ ${ }^{3}$ Institute for Global Health, University College London \\ ${ }^{4}$ University of Adger
}

Received: 12 November 2016 / Accepted: 17 July 2017 / Published online: 25 July 2017

\begin{abstract}
In many small island developing states (SIDS), tourism is a principal driver of the economy and of infrastructure development. The SIDS' tourism sector is, however, threatened by climate change impacts, which will likely incur high costs for climate change adaptation (CCA). Discussions are starting about who should pay for the costs of adapting to climate change, especially the balance amongst sectors such as between governments and the tourism industry. Through the perceptions of selected industry stakeholders, this study explores the potential of the tourism industry in SIDS in financing its own CCA. Fiscal and political mechanisms were examined, such as adaptation taxes and levies, adaptation funds, building regulations, and risk transference. The study's exploratory method combines nine indepth key stakeholder interviews from various SIDS and an extensive literature review to develop a schematic of suggested mechanisms. The results reveal a high overall potential for the tourism industry funding its CCA, but with significant challenges in realizing this potential. Consumer expectations and demands, governmental hesitation in creating perceived investment barriers, and assumptions about cost effectiveness could undermine steps moving forward. Varying incentive structures, the sector's price sensitivity, and the differing abilities of tourism industry stakeholders to adapt are factors suggesting that government frameworks are needed to ensure effective and substantive action.
\end{abstract}

Keywords: Climate change $\cdot$ adaptation $\cdot$ climate finance $\cdot$ islands $\cdot$ SIDS $\cdot$ small island developing states DOI: https://doi.org/10.18783/cddj.v002.i02.a04

Corresponding Author:

Janto S. Hess

Janto.Hess.15@ucl.ac.uk 


\section{Introduction}

Small Island Developing States or SIDS are several countries said to have similar development challenges and opportunities (United Nations Framework Convention on Climate Change [UNFCCC], 2007). They are particularly vulnerable to climate change, especially to impacts such as sea-level rise, changing frequencies and intensities of weather extremes, coastal flooding and erosion, and ocean acidification (UNFCCC, 2015; Nurse et al., 2014); but they also display significant resilience to challenges faced (Gaillard, 2007; Lewis, 1999), albeit with significant financial burden on their governments and economic sectors to adapt to and recover from climate change impacts.

To help cope with these costs, USD 100 billion of international climate finance was pledged annually from 2020 onwards to support developing countries in tackling climate change impacts, with SIDS prioritized as recipients (UNFCCC, 2015). The USD 100 billion is supposed to come from both private and public sources, yet the private sector's involvement remains unclear and creates challenges (United Nations Environmental Programme [UNEP], 2016; Dzebo \& Pauw, 2014). Available data on private sector contributions to adaptation is sparse (Brown et al., 2015; Buchner, Trabacchi, Mazza, Abramskiehn, \& Wang, 2015). Buchner et al. (2015) estimated an overall contribution by the private sector of USD 245 billion in 2014 for dealing with climate change.

Many SIDS are experiencing climate change impacts and need financial resources to adapt (Intergovernmental Panel on Climate Change [IPCC], 2014a). Climate change adaptation (CCA) is "[t]he process of adjustment to actual or expected climate and its effects. In human systems, adaptation seeks to moderate or avoid harm or exploit beneficial opportunities" (IPCC, 2014b, p. 118). CCA finance is understood as comprising all financial resources that are mobilised, pledged, or spent on adaptation.

One of the main economic sectors for many SIDS (Connell, 2013; United Nations World Tourism Organization [UNWTO], 2012; Scheyvens \& Momsen, 2008) is tourism, which is considered as one of the biggest global industries (UNWTO, 2016). SIDS governments frequently support the tourism industry financially, including paying for development, due to its assumed benefits such as generating employment, fostering development, generating tax revenues, and justifying the value of protecting natural resources. But climate change is projected to exacerbate existing development challenges, such as fresh water supply and infrastructure resilience to storms, indicating the need for the tourism industry to adapt (Scott, Hall, \& Gössling, 2016; IPCC, 2014a; Scott, Gössling, \& Hall, 2012; UNWTO, UNEP, \& World Meteorological Organization [WMO], 2008). This setting leads to an inquiry whether it is the SIDS' governments or the tourism industry that should pay for all CCA initiatives in the tourism industry, or if these costs should be shared between them.

The SIDS tourism industry could be encouraged to support adaptation financing due to its dependency on SIDS' destination attributes and activities, such as beaches and diving. Other concerns could also emerge, providing impetus for supporting adaptation financing. In some SIDS locations, tourists' use of water and energy is a concern or tackling eroding shorelines is priority. Consequently, multiple reasons might emerge, but the short-term thinking of some sector stakeholders needs to be considered, in that parts of the tourism industry might be seeking the quickest way of achieving maximum profit.

This paper explored the potential for involving the tourism industry in SIDS to fund its own CCA by examining views of potential roles which the industry could play.

\section{SIDS in the Context of International Tourism and Climate Change}

In many SIDS, the tourism industry generates a significant share of the country's gross domestic product (GDP). For example, tourism share was estimated at $76.8 \%$ of GDP in Palau in 2012 (Central Intelligence Agency [CIA], 2014), at 47.3\% in Vanuatu in 2015 (World Travel and Tourism Council [WTTC], 2016b) and at 38.7\% in Fiji in the same year (WTTC, 2016a). Tourism is often perceived as a key development option for SIDS, especially when exports face significant constraints due to high transportation costs, market entry barriers, and unfavourable trade agreements (UNWTO, 2012; Brau, Liberto, \& Pigliaru, 2011; Bishop, 2010; Narayan, Narayan, Prasad, \&Prasad, 2010; Croes, 2006). However, tourism markets are particularly vulnerable to sudden changes, such as from the global economy, perceptions of political unrest and violence, and media portrayals of adverse environmental impacts (Connell, 2013; Graci \& Dodds, 2010). The impacts of specific events on visitor numbers can be short-lived, but structural or longterm changes, such as from climate change, can significantly alter a destination's perceived or actual functionality and appeal (Mahon, Becken, \& Rennie, 2013; Narayan et al., 2010; Gössling, Bredberg, Randow, Sandstrom, \& Svensson, 2006).

Projected climate change impacts on SIDS include changing patterns of weather extremes, water scarcity, biodiversity loss, sea-level rise, and ocean acidification (c.f. IPCC, 2014a; Gössling et al., 2012; Scott et al., 2012; Becken \& Hay, 2007). Table 1 shows how such impacts can affect the tourism sector, especially through reputational risks, threatening the attractiveness of SIDS as tourist destinations or perceptions thereof (Shakeela \& Becken, 2015; Mahon et al., 2013; Wright, 2013; Gössling et al., 2006). Ironically, the demand for this market segment, and government policies to support it, produces a pattern of coastal zone tourism development that can further increase the place's vulnerability to weather extremes (Juhasz, Ho, Bender, \& Fong, 2010; Allison, 1996).

Table 1. Illustrative impacts of climate change on tourism in SIDS (based on IPCC, 2014a; Scott et al., 2012; UNWTO et al., 2008)

\begin{tabular}{lll}
\hline $\begin{array}{l}\text { Climate } \\
\text { change effect }\end{array}$ & $\begin{array}{l}\text { Tourism } \\
\text { impacts }\end{array}$ & $\begin{array}{l}\text { Tourism } \\
\text { impacts }\end{array}$ \\
\hline Sea-level rise & $\begin{array}{l}\text { Coastal erosion, } \\
\text { beach loss }\end{array}$ & $\begin{array}{l}\text { Clearing coastal } \\
\text { areas of vegetation, }\end{array}$ \\
\hline
\end{tabular}


Table 1 (Continued)

\begin{tabular}{lll}
\hline $\begin{array}{l}\text { Climate } \\
\text { change effect }\end{array}$ & $\begin{array}{l}\text { Tourism } \\
\text { impacts }\end{array}$ & $\begin{array}{l}\text { Tourism } \\
\text { impacts }\end{array}$ \\
\hline $\begin{array}{l}\text { Sea-level rise } \\
\text { (Continued) }\end{array}$ & & $\begin{array}{l}\text { artificial beach } \\
\text { nourishment }\end{array}$ \\
\hline
\end{tabular}

\section{A changing storm} regime

\section{Damage to tourism facilites, increased insurance costs, business interruption \\ Developing tourism infrastructure in hazard-prone areas, poor quality of building design and materials, insufficient disaster risk reduction and disaster management}

$\begin{array}{lll}\begin{array}{l}\text { Biodiversity } \\ \text { changes }\end{array} & \begin{array}{l}\text { Loss of natural } \\ \text { attractions and } \\ \text { species from } \\ \text { destinations, } \\ \text { especially for coral } \\ \text { reefs }\end{array} & \begin{array}{l}\text { Pollution, poor } \\ \text { waste and waste- } \\ \text { water management, } \\ \text { disturbance of } \\ \text { animals in protected } \\ \text { areas, reduction } \\ \text { of and damage to } \\ \text { natural habitats }\end{array} \\ & \begin{array}{l}\text { Heat stress for } \\ \text { tourists, increased } \\ \text { cooling costs, coral } \\ \text { bleaching }\end{array} & \begin{array}{l}\text { Inadequate building } \\ \text { design, reduction } \\ \text { of tree cover and } \\ \text { namperatures }\end{array} \\ \begin{array}{ll}\text { natural shading } \\ \text { options }\end{array}\end{array}$

\section{Private Sector Involvement in Climate Adaptation Finance}

After the initial pledge to provide USD 100 billion annually by 2020 , private sector involvement in adaptation finance was increasingly highlighted (UNEP, 2016; Pauw \& Pegels, 2013; Atteridge, 2011). In this article, the term 'private sector' is primarily understood as any privately-owned enterprise. The private sector will likely have to adapt, and in many cases already adapts, to climate change through exploiting new business opportunities and managing climate-related risks (Pauw, 2015; Surminski, 2013). Tracking private finance in adaptation is a major challenge due to scarcity of information (Pauw, 2015; Agrawala et al., 2011).

Much investment in adaptation is not officially declared, tracked, or labelled as such, instead takes place through incremental changes and adjustments of infrastructure and responses to changing demand patterns (Christiansen, Ray, Smith, \& Haites, 2012). Having little data does not mean an absence of adaptation investments. Case studies verify that adaptation and its financing take place on different levels, e.g., by small- and medium-sized enterprises (UNFCCC, 2014; Bradshaw, Dolan, \& Smit, 2004; Qiu \& Prato, 2012) and by large companies (UNFCCC, 2016; Kolk \& Pinkse, 2005).
There was a proposal to raise USD 8 to 10 billion annually through an International Air Passenger Adaptation Levy (IAPAL) for financing adaptation in developing countries (Müller, 2008). In 2008, the UN's group of Least Developed Countries proposed to include the IAPAL within the UNFCCC Bali Action Plan, but they did not succeed (Scott \& Becken, 2010). The proposal shows that the tourism sector has some potential for becoming a major source of adaptation financing. Concerns were raised, however, about possible impacts of such a levy on global air travel dynamics and its consequences for tourism-dependent SIDS. Nevertheless, one investigation concluded that "the potential benefits of IAPAL for countries reliant on tourism are likely to outweigh the costs of slightly reduced tourist numbers" (Chambwera, Njewa, \& Loga, n.d., p. 12), implying that the industry would not be harmed by such a levy and that industry supporting the levy would see an adequate return on investment.

In the end, the private sector "will expect the same return on their investment ['risk premium'] in adaptation that is available from other investments with a similar risk profile" (Christiansen et al., 2012, p. 8). Uncertainties for tourism in SIDS include: (i) unclear magnitudes and time scales of regional and local climate change impacts; (ii) public policy changes and reliability; (iii) political instability; (iv) development of international tourism flows; (v) non-transparent and unreliable political systems; and (vi) limited ability and experience for diversifying risks amongst different economic sectors (Transparency International, 2016; Ackerman \& Stanton, 2013; Buchner et al., 2013; Connell, 2013; Wong, de Lacy, \& Jiang, 2007; Schelling, 2007). In other words, the largest uncertainties come from human responses to climate change rather than from climate change itself, which is a challenge for the private sector to respond to when many of the responses are government-led.

\section{Methodology}

This exploratory study is based on a mixed methods approach and brings together findings from the literature and a stakeholder approach comprising nine semi-structured, indepth interviews. An initial literature review and analysis identified six mechanisms which are relevant and feasible for involving the tourism industry in financing its own adaptation. An in-depth literature review ensued.

In terms of the stakeholder approach and within the context of climate change uncertainties and how humanity might respond to the impacts, stakeholder theory can further enrich the understanding of the potential interest and perspectives of the tourism industry in financing its adaptation. A stakeholder is "any group or individual who can affect or is affected by the achievement or the organisation's objective" (Freeman, 1984, p. 46). Stakeholder theory can be understood as "a theory of organizational management and ethics" exploring the interaction between a company and their stakeholders (Phillips, Freeman, \& Wick, 2003, p. 480). A range of papers has debated 
if the natural environment, and as a part of it climate change, could be considered as being a stakeholder, with some arguing for it (e.g., Haigh \& Griffiths, 2009; Kolk \& Pinkse, 2005; Starik, 1995) and some against it (e.g., Orts \& Strudler, 2002; Phillips \& Reichart, 2000).

Given this debate, it is important to acknowledge that the natural environment and climate change impacts must be considered in businesses' strategic management processes (Haigh \& Griffiths, 2009). Due to the relatively small land and population size of SIDS, there tends to be fewer stakeholders overall, especially in the private sector, meaning that any given stakeholder's actions or reactions can lead to comparatively bigger domestic impacts than in other countries. Thus, for enterprises in a SIDS context, incorporating their stakeholders' climate change impacts and adaptation actions is of strategic interest, since the close interdependencies amongst the stakeholders mean that one stakeholder's decisions can have significant ripple effects around the country.

Using the stakeholder approach, the in-depth interviews explored potential attributes and perceptions of selected stakeholders in the industry on the mechanisms and CCA financing more generally. Many papers examining international tourism have used a comparable number of qualitative, in-depth interviews, demonstrating how a small but targeted sample size can lead to rich findings (Osorio \& Best, 2015; Mansfeld \& Korman, 2015; Wong et al., 2012).

The interviews were conducted in person (five participants) and via Skype (four participants) during two months in mid-2014, completed in English (common language of the interviewer and all interviewees), based on open-ended and follow-up questions, and lasted 45 minutes on average. All interview partners were offered anonymity, an option accepted by only the tour operator representatives. Table 2 provides an overview of the interviewees. These individuals were selected based on their (i) expertise on the topic and (ii) representing a broad range of stakeholders from the tourism industry, donor organisations, and local governments. Most interviews with government representatives were conducted at an international climate change negotiations event in Bonn. The other interviewees were identified through reviewing existing literature and recommendations from other interviewees (snowball sampling).

Table 2. Overview of interviewees

\begin{tabular}{|c|c|c|c|}
\hline Abbr & $\begin{array}{l}\text { Operating } \\
\text { Location }\end{array}$ & Institution & Position \\
\hline SL & St. Lucia & $\begin{array}{l}\text { Ministry of Sustainable } \\
\text { Development, Energy, Science } \\
\text { and Technology }\end{array}$ & $\begin{array}{l}\text { Chief Sustainable } \\
\text { Development \& } \\
\text { Environment Officer }\end{array}$ \\
\hline PNG & $\begin{array}{l}\text { Papua New } \\
\text { Guinea }\end{array}$ & $\begin{array}{l}\text { Office of Climate Change and } \\
\text { Development, Government of PNG }\end{array}$ & $\begin{array}{l}\text { Manager of Reducing } \\
\text { Emissions from } \\
\text { Deforestation and Forest } \\
\text { Degradation Projects }\end{array}$ \\
\hline
\end{tabular}

\begin{tabular}{|c|c|c|c|}
\hline Abbr & $\begin{array}{l}\text { Operating } \\
\text { Location }\end{array}$ & Institution & Position \\
\hline MA & Mauritius & $\begin{array}{l}\text { Ministry of Environment \& } \\
\text { Sustainable Development }\end{array}$ & $\begin{array}{l}\text { Divisional Environment } \\
\text { Officer }\end{array}$ \\
\hline SI & $\begin{array}{l}\text { Solomon } \\
\text { Islands }\end{array}$ & $\begin{array}{l}\text { Ministry of Environment, } \\
\text { Climate Change, Disaster } \\
\text { Management and Meteorology }\end{array}$ & $\begin{array}{l}\text { Under Secretary / } \\
\text { Technical }\end{array}$ \\
\hline UN & Mauritius & $\begin{array}{l}\text { United Nations Development } \\
\text { Programme }\end{array}$ & $\begin{array}{l}\text { Regional Technical } \\
\text { Adviser }\end{array}$ \\
\hline UNW & $\begin{array}{l}\text { South East } \\
\text { Asia }\end{array}$ & $\begin{array}{l}\text { United Nations World Tourism } \\
\text { Organization, Consulting Unit } \\
\text { on Tourism and Biodiversity }\end{array}$ & $\begin{array}{l}\text { Project Manager, } \\
\text { Sustainable } \\
\text { Development for } \\
\text { Tourism }\end{array}$ \\
\hline TO1 & $\begin{array}{l}\text { Carribean, } \\
\text { Africa, } \\
\text { Indian } \\
\text { Ocean }\end{array}$ & $\begin{array}{l}\text { Tourism Operator } 1 \text {, } \\
\text { multinational tourism } \\
\text { corporation within the range } \\
\text { of the } 5 \text { biggest tour operators } \\
\text { in Europe }\end{array}$ & $\begin{array}{l}\text { Head of Sustainability } \\
\text { Management }\end{array}$ \\
\hline TO2 & $\begin{array}{l}\text { Carribean, } \\
\text { Africa, } \\
\text { Indian } \\
\text { Ocean }\end{array}$ & $\begin{array}{l}\text { Tour Operator } 2 \text {, multinational } \\
\text { tourism corporation within } \\
\text { the range of the } 5 \text { biggest tour } \\
\text { operators in Europe }\end{array}$ & Higher Management \\
\hline WT & Globally & $\begin{array}{l}\text { World Travel and Tourism } \\
\text { Council }\end{array}$ & $\begin{array}{l}\text { Policy and Research } \\
\text { Director }\end{array}$ \\
\hline
\end{tabular}

The semi-structured interviews were recorded, transcribed, coded, and analysed qualitatively (Liamputtong, 2013; Bryman, 2012; Babbie, 2010) to extract details for and interviewees' perceptions regarding each investigated mechanism. The findings were further enriched through a targeted literature search identifying existing examples and attributes of each mechanism. The main limitation of the data is the underrepresented tourism industry stakeholders, such as from accommodation, boating, and diving; however, the interviewees indicated that they work closely with these sectors and revealed insights into their perceptions, helping to overcome this gap.

\section{Mechanisms for Involving the Tourism Industry in Adaptation Finance}

The results demonstrated stakeholder perceptions of CCA financing for the tourism industry and provided details of six mechanisms for involving the industry in financing its adaptation, namely: (i) public-private partnerships (PPPs); (ii) building standards and regulations; (iii) adaptation taxes or levies; (iv) adaptation funds; (v) water use management; and (vi) risk transfer mechanisms.

\section{Perceptions of and on Key Stakeholders}

Most interviewees estimated the tourism industry's awareness of climate change as being high. Climate change is apparently recognized by the industry as a big 'trend' that will affect business in the future. At annual business summits of the largest global lobby organisation of the industry, climate change "always comes up whether [they] plan to talk about 
it or not" (WT). Studies confirmed this perception on climate change of the tourism industry in SIDS (Belle \& Bramwell, 2005; Méheux \& Parker, 2006).

Awareness does not automatically lead to action. In fact, the overall willingness of the sector to participate in financing CCA was estimated as being low by seven of the nine interviewees, even though it is highly context-dependent. The type of tourism enterprise, their abilities to deal with climate change, and the level of potential benefits of an adaptation measure for their business were key factors shaping the willingness to participate in funding adaptation (TO1, TO2, WT, UNW). The tourism industry representatives also considered governments to be responsible for many adaptation actions (WT, TO2). Another major concern raised by private sector representatives was the transparency of financial flows within local governments (TO1, TO2, WT).

WT, similarly to Pauw \& Pegels (2013), raised the question of whether the private sector actually "bothers about" or understands adaptation terminology. They suggested that many enterprises incorporate adaptation measures, and thus fund them, in their daily activities without being aware that they could be termed 'adaptation' or labelling them as such. Other reasons for inactivity (Wright, 2013; Becken \& Hay, 2012; Sovacool, 2012; Becken, Hay, \& Espiner, 2010; Turton et al., 2010) included: (i) uncertainties about climate change impacts as well as the context of other changes being experienced; (ii) most objects of attraction for tourists being 'common goods' and, therefore, government owned or managed; (iii) the conflicting time horizon of climate projections, regular economic investments, and expectations of return-oninvestment; and (iv) the framing of climate change in relation to other more immediate challenges to economic profitability.

The latter could also translate into governmental priority setting. Governments often become more concerned about immediate matters rather than aiming for long-term adaptation strategies, or they need to make policy decisions in a "context of uncertainty and complex socio-economic, cultural, and political relationships" (Belle \& Bramwell, 2005; UNW). The government interviewees revealed that they were also cautious about creating extra burdens (or something perceived as such) for the already competitive and price-sensitive tourism industry through taxes and regulations (SL, PNG, MA, SI).

Regardless, adaptation measures would have the highest chance of being implemented when mutual benefits are created, especially in the short-term(UNW, TO1, TO2). The government could aid such a process through reducing uncertainty through legal security, clear public policies, transparency, and incentive frameworks that are influential factors in attracting and sustaining tourism investment (Christiansen et al., 2012; Persson et al., 2009).

\section{Public-Private Partnerships (PPPs)}

PPPs can be broadly outlined as arrangements between the public and the private sectors (Hodge \& Greve, 2007). There is not a single, widely accepted definition of PPP, but most definitions include it as being a form of collaboration to pool resources for reaching a common aspiration (UNWTO, 2015; Grimsey \& Lewis, 2004; Osborne \& Murray, 2000; Gray, 1991).

A key determining factor of PPP initiation is expectation of mutually beneficial outcomes, at least in theory. The main incentives for initiating PPPs can be combining specific qualities, such as know-how, of both public and private sectors to create a better result (Rosenau, 2000) by using the innovative capacity of the private sector and potentially garnering additional funding (Christiansen et al., 2012; Hodge $\&$ Greve, 2007). In particular for many SIDS with a limited public budget and small development agencies, this can be an important motivation to realize PPP projects. Thus, "PPPs are important, and often vital, elements in the establishment of tourism-based initiatives and the improvement of the market competitiveness of destinations" (UNWTO, 2015, p. 12).

The UNWTO representative saw a high potential for international donors to initiate PPPs for adaptation in SIDS. However, "the extent to which PPP[s] [are currently] employed in climate adaptation is very limited, and even more so in the tourism sector" (Wong et al., 2012, p. 136). Wong et al. (2012, p. 136) investigated "if and how ... [PPPs] may help the tourism sector in ... [SIDS] in the South Pacific [to] adapt", concluding that the tourism sector stakeholders "were positive about forming PPPs for adaptation" (Wong et al., 2012, p. 140), although one critic did not trust the reliability of the government as a potential partner.

The main barriers to PPPs for the tourism industry were identified as (Wong et al., 2012; WT; Huxham \& Vangen, 2002): (i) limited interest in participating financially in projects run by or with stakeholders who can adapt in other ways (TO1, TO2); (ii) setting common aims; (iii) trust; (iv) and differences in work culture. Despite good practice examples, PPPs experienced a range of bad circumstances and were criticized about their effectiveness. This criticism covers: (i) privatizing government assets and services through PPPs which effectively yields ownership to the private sector with limited interest in public goods; (ii) limited transparency; (iii) unsuccessful transfer of risks, and (iv) mainly driven by industry rather than public interests (Roehrich, Lewis, \& George, 2014; Sanger \& Crawley, 2009; Hodge \& Greve, 2007; Hodge, 2004).

Overall, PPPs appear to be a promising mechanism to realize adaptation projects, particularly of large infrastructure interventions. Competing interests, constraints, and stakeholder perceptions need to be factored in when designing measures. Building Standards and Regulations

High quality building standards for SIDS' tourist infrastructure can significantly decrease the negative impacts of climate change (Mahon et al., 2013). Conversely, the quality of water and resource management can suffer in the absence of regulations. In SIDS, much accommodation was built on or near the seafront 
in order to fulfil customer desires for beach and water tourism. Thus, tourism developers often took a calculated risk in locating their business on the shoreline, if governmental regulations are absent (Mahon et al., 2013) — and sometimes even when there are governmental regulations against the practice. The tour operator representatives clearly stated that this situation relates to their business practices of cooperating only with resorts close to the shoreline, since tourist demand patterns highlight beachside locations (TO1, TO2).

All countries represented by an interviewee, apart from Mauritius where such laws are currently being drafted, have specific building codes that consider climate change impacts, such as sea-level rise (MA, PNG, SI, SL). From the authors' perspective, there might be a self-selection bias in that representatives from other governments potentially did not make themselves available for interviews due to lack of interest in managing the tourism industry. Yet code enforcement seems to be a major challenge in all the participating countries (SI, SL, MA). Another major issue was that rebuilding tourism infrastructure after disasters often takes place in the same disaster-prone areas (Mahon et al., 2013). Regulatory frameworks to support the industry in dealing with climate change impacts can include monitoring and maintenance regimes within building codes; full planning and design standards and regulations; and professional certification for engineers, architects, and planners. It remained an open question if such regulations would be enforced in an economy that is highly dependent on tourism, even though enforced building standards tend to make a positive impact on adaptation and wider risk reduction (Spence, 2004).

\section{Adaptation Taxes or Levies}

Taxation or levy systems could generate additional funds to finance adaptation measures. At the moment, no such specific adaptation taxes or levies for the tourism industry are implemented in any of the islands represented by interviewees. Although many SIDS have departure taxes/tolls or 'green' fees for tourists, none directly addresses or funds adaptation. MA, PNG, and SI indicated that they are very cautious about creating an extra burden (or something perceived as being a burden) on the increasingly competitive tourism enterprises operating in their countries. WT stated, "generally speaking, taxing tourism is not helpful; tourism is enormously pricesensitive". Apart from these concerns towards regulation, two interviewees said that fiscal mechanisms such as taxes or levies would be the most efficient way to raise funds for adaptation (TO1, TO2). Governments could also use funding from taxes independently for adaptation interventions.

This autonomous management of funding was, on the other hand, a big concern raised by the industry (TO1, TO2, WT). They mentioned that taxes in many cases were used to "fix holes in national budgets" and they were afraid that adaptation taxes could be misused or even disappear in other channels. Therefore, a clear trust issue emerged and any taxation system would need to be transparent and carefully designed so as not to trigger negative consequences, or perceived negative consequences, for the sector. Transparency International's (2016) corruption perceptions index gives wide-ranging results for tourism-dependent SIDS (e.g., Barbados is tied with the USA at \#16, but Dominican Republic is ranked at \#103), although most SIDS are not listed. Fiji, for instance, is not listed and has a high rate of corruption perceptions (Pathak, Naz, Rahman, Smith, \& Nayan Agarwal, 2009).

\section{Adaptation Funds}

Adaptation funds are funds that are created to pool finance to incentivize action or invest in adaptation measures, projects, or programmes. Adaptation funds could be set up at any governance level: global, regional, national, or local. Most interviewees rated adaptation funds as being a feasible mechanism (UNW, UN, MA, SL, SI, TO1). All industry representatives preferred adaptation funds as a way to finance adaptation when compared to taxes or levies (TO1, TO2, WT). Regional, national, or local funds were perceived to be better than international ones due to fewer organisational challenges and the possibility of reconciling differing interests.

Regional and local funds could be initiated, sourced, and managed by governments, independent institutions, and/or the private sector (WT). The capital raised was suggested as financing mainly visible adaptation measures, such as building structural defences along the shoreline (ex-post) or rebuilding infrastructure to factor in climate change impacts (ex-ante).

No country was identified as having a tourism industry that implemented a climate adaptation fund as part of its funding structure. However, the Caribbean region implemented the Caribbean Catastrophe Risk Insurance Facility (CCRIF), which could be interpreted as functioning in a comparable manner to an ex-post orientated adaptation fund (CCRIF, 2014). PNG, SI, and MA were all positive about implementing such funds in their region and currently plan to set up a national climate change fund that partly finances adaptation. Nonetheless, they were cautious about involving the tourism industry as a source of funding (MA, SI), as in their view, doing so could potentially discourage the industry from investing. This reaction once more demonstrated the dependency (or assumed dependency) of SIDS on the tourism sector, along with the assumption that requests or demands for adaptation financing will limit investment in tourism, thereby limiting the governments' negotiating power. As potential countermeasures, increasing a fund's transparency and possibly involving the tourism sector as managing board members seemed to raise the industries' acceptance of such a mechanism (TO2, WT).

\section{Water Use Management}

Another potential mechanism to fund CCA efforts in the tourism industry is sustainable water management practices for both demand and supply, including the treatment of wastewater 
to avoid health impacts and the reduction of overall water use. Sustainable water management practices are always needed, given how excessive water use can be in the tourism industry (Garcia \& Servera, 2003); but such measures can only be regarded as adaptive in nature, particularly in destinations where climate change impacts the availability of fresh water or the negative consequences of untreated wastewater. These trends are expected in most SIDS due to saltwater intrusion driven by sea-level rise (IPCC, 2014b; UNWTO et al., 2008). Some SIDS already import fresh water using tanker ships, including Fiji, Tonga, Bahamas, Antigua and Barbuda, and Nauru (United Nations Educational, Scientific and Cultural Organization [UNESCO], 2012). This problem is further reinforced by tourism development trends towards higher fresh water use, leading to the situation wherein "tourism development in many areas of the world may become less sustainable or no longer feasible" (Gössling et al., 2012, p. 13; Charara, Cashman, Bonnell, \& Gehr, 2011; Bishop, 2010).

Apart from the constraint of water availability for tourism, poor water quality and media coverage of water issues can create image problems for destinations (Hall, 2010; Hall \& Stoffels, 2006), implying a need for tourism to engage more proactively in water management (van der Velde, Green, Vanclooster, \& Clothier, 2007; Hall \& Härkönen, 2006). A positive aspect of improved water management is the potential to simultaneously reduce costs since "it seems beyond doubt that most of the measures that can reduce water use are economical" (Gössling et al., 2012, p. 13). The UNWTO representative stated that this framing of the environmental problem in economic terms was in his experience the key strategy for convincing the private sector to act in a developing country context.

\section{Risk Transfer Mechanisms}

The most common risk sharing and transfer mechanisms in the tourism sector are insurance-related schemes, in which investments could easily be tracked. These mechanisms usually "manage risks that would be too large for companies or individuals to cover on their own" (Warner et al., 2013, p. 11). Particularly in the context of climate change, they could play a key role for tourism firms in managing risk and enabling investments and operations despite uncertainties under climate change.

While insurance can raise awareness about risk management and adaptation, "climate change may bring some residual risks which cannot be transferred to the insurance market costeffectively" (Warner et al., 2013, p. 13) and might discourage adaptation. UNFCCC (2012) estimated that for countries which are highly exposed to slow-onset climatic processes, such as sea-level rise, traditional risk transfer approaches could be unsuitable. This is the case if two main preconditions for traditional insurance schemes to work are not fully applicable (Warner et al., 2013, p. 14): "the unpredictability of a specific event and ability to spread risk over time and regions, between individuals/entities".
An alternative investigated and piloted scheme is weatherindex based insurance products (Munich Climate Insurance Initiatives [MCII], 2014). In contrast to traditional insurance schemes, the weather-index based payout allows an immediate payout after a disaster, thus payouts are not bound to the value of the asset, but insurance credits can be purchased and payouts are related to the amount of credits which an enterprise holds. Most of the country representatives had already heard about such schemes, in contrast to the industry representatives, although the interviewees stated that majority of the bigger tourism enterprises in SIDS are already insured.

\section{Discussion}

Based on the mechanisms identified by the interviewees and literature, this section discusses the influence of interests and operational scales on the feasibility of implementing the mechanisms.

The results imply that the tourism industry is more likely to support some mechanisms than others, mainly emerging from the tour operator representatives stating that they cannot use adaptation projects as effective marketing tools. Considering the possible drivers for the private sector to invest in its own CCA (Pauw \& Scholz, 2012), the industry interviewees indicated interest in protecting their business from negative impacts through risk transfer mechanisms and exploiting beneficial opportunities through water management. Corporate social responsibility was rarely mentioned and could not be depicted directly by any single mechanism, whereas water efficiency could possibly be used for marketing purposes.

While the responses indicate that industry representatives have a limited understanding of adaptation and its benefits, this does not translate to invalid views. Rather, an improved understanding could yield a higher and more positive perspective and motivation for the tourism industry to fund its own CCA. Informational programs from SIDS governments might convince the tourism industry to be more involved in financing its $\mathrm{CCA}$ - or could at least seed the ideas for the tourism industry to start engaging in dialogue with governments.

The other identified mechanisms appear to have fewer direct positive rewards for the industry, so the interviewees intimated reluctance to incur the additional costs assumed to be required, corroborating earlier findings from Fiji (Becken, 2005). Similarly, Sovacool, Linnér, and Klein (2017) document limited results from an adaptation fund for Maldives and Vanuatu, amongst other countries, raising the question of why the tourism industry should contribute to such a fund. Thus, the mechanisms can be clustered according to the perceived interests of government and of the private sector in initiating the mechanism for increasing adaptation financing (Figure 1). SIDS governments would 
need to play a significant role in initiating mechanisms, but then they might give in to tourism industry lobbying against the mechanisms based on perceived costs.

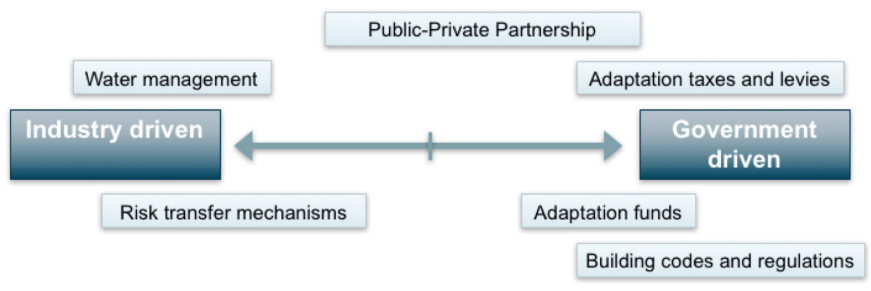

Figure 1. Categorisation of mechanisms on CCA financing according to the likely initiator

In this context, the differing operational scales and abilities of stakeholders for dealing with climate change should be considered for a clearer picture of the feasibility of implementing certain mechanisms. Interest in adaptation engagement tends to be lower where adaptive capacities are higher and vice versa (Hess, Pauw, \& Papyrakis, 2015), suggesting that the industry might favour certain mechanisms precisely because these stakeholders feel that their adaptive capacities are low, so they need to act. Industry stakeholders who are bound to a specific location, such as hotels, beach owners, and protected area tour operators, tend to be less flexible for relocating their operations, if it is even possible, thereby increasing exposure to risks and potentially favouring prompt adaptation action.

SIDS governments should therefore consider factoring in industry operational scale and interests when deciding how to act on financing tourism industry adaptation. This conclusion is supported by Pauw, Klein, Vellinga, and Biermann (2016) who detailed specific limitations for monitoring and reporting private sector financing for climate adaptation. In fact, the results demonstrate that, whereas multinational tour operators tend to have the highest flexibility for selecting and adjusting mechanisms, their willingness to finance adaptation appears to be low. Conversely, the tendency is the opposite for more locally bound stakeholders. Nonetheless, businesses looking towards the long-term, or businesses seeking government direction because the industry's adaptability is low, might be supportive of government interventions.

\section{Conclusion and Recommendations}

This exploratory study showed that several promising mechanisms exist for involving the tourism industry in financing its own CCA in SIDS as viewed by the interview respondents. The industry representatives perceived that the willingness to become involved may vary significantly due to differences in the industry's knowledge of, ability in, and interest regarding CCA as well as their operational scale. On a destination or regional scale, adaptation funds, risk transfer mechanisms, and PPPs proved to be particularly promising. Overall, private adaptation financing initiatives were widely acknowledged by the interviewees as being preferable, as they are seen to be more transparent than taxes or levies, while the industry could hold positions on the fund's management board.

Despite the overall potential, in-depth interviews and literature review pointed to a number of challenges in involving the tourism industry in financing its own CCA in SIDS. Varying incentive structures and the price sensitivity of the sector suggest that government frameworks would be needed to effect substantive action. Moreover, this study showed that approaching the sector to support adaptation financing should likely be based on demonstrating cost-effective interventions or possible costly threats. Such an approach typically increases the chances of gaining the attention of firms, raising awareness, and creating a knowledge base on which the necessity of supporting adaptation action could be communicated.

Further research should be undertaken to supplement these exploratory findings for each identified mechanism and for possible interactions amongst them. Building on the findings of the study, follow-up stakeholder group interviews in SIDS could reveal how stakeholder interdependencies and power dynamics could further shape the potential of involving the SIDS tourism industry in adaptation financing. Quantitative surveys alongside qualitative interviews covering more stakeholders could be undertaken to determine the wider tourism industry stakeholders' perceptions of mandatory and voluntary involvement in adaptation financing. The data would contribute to scoping the practicality and feasibility of implementing certain mechanisms in specific SIDS contexts. The opportunity also exists to further test assumptions of stakeholder theory in SIDS contexts, to indicate whether or not the theory would need to be modified to account for the small, closely knit populations. Thus, continuing to examine tourism industry financing of CCA in SIDS can make both theoretical and empirical contributions to the literature.

\section{References}

Ackerman, F., \& Stanton, E. A. (2013). Climate economics: the state of the art. London; New York: Routledge.

Agrawala, S., Carraro, M., Kingsmill, N., Lanzi, E., Mullan, M., \& Prudent-Richard, G. (2011). Private Sector Engagement in Adaptation to Climate Change (OECD Environment Working Papers No. 39). Organisation for Economic Co-operation and Development.

Allison, W. R. (1996). Snorkeler damage to reef corals in the Maldive Islands. Coral Reefs, 15(4), 215-218. https://doi. org/10.1007/BF01787454

Atteridge, A. (2011). Will Private Finance Support Climate Change Adaptation in Developing Countries?: Historical 
Investment Patterns as a Window on Future Private Climate Finance (Working Paper 2011). Stockholm: Stockholm Environment Institute. Retrieved from http://www.seiinternational.org/mediamanager/documents/Publications/SEIWorkingPaper-Atteridge-WillPrivateFinanceSupportClimate ChangeAdaptationInDevelopingCountries-2011.pdf

Babbie, E. R. (2010). The practice of social research (12th ed). Belmont, California: Wadsworth Cengage.

Becken, S. (2005). Harmonising climate change adaptation and mitigation: The case of tourist resorts in Fiji. Global Environmental Change, 15(4), 381-393. https://doi. org/10.1016/j.gloenvcha.2005.08.001

Becken, S., \& Hay, J. E. (2007). Tourism and climate change risks and opportunities. Clevedon, UK; Buffalo: Channel View Publications. Retrieved from http://site.ebrary.com/id/10189013

Becken, S., \& Hay, J. E. (2012). Climate change and tourism: from policy to practice. New York: Routledge.

Becken, S., Hay, J., \& Espiner, S. (2010). The risk of climate change for tourism in the Maldives. In J. Carlsen \& R. Butler (Eds.), Island tourism: towards a sustainable perspective (pp. 72-84). Wallingford, Oxfordshire, [England] ; Cambridge, MA: CABI.

Belle, N., \& Bramwell, B. (2005). Climate Change and Small Island Tourism: Policy Maker and Industry Perspectives in Barbados. Journal of Travel Research, 44(1), 32-41. https:// doi.org/10.1177/0047287505276589

Bishop, M. L. (2010). Tourism as a Small-State Development Strategy Pier Pressure In The Eastern Caribbean? Progress in Development Studies, 10(2), 99-114. https://doi. org/10.1177/146499340901000201

Bradshaw, B., Dolan, H., \& Smit, B. (2004). Farm-Level Adaptation to Climatic Variability and Change: Crop Diversification in the Canadian Prairies. Climatic Change, 67(1), 119-141. https:// doi.org/10.1007/s10584-004-0710-z

Brau, R., Liberto, D., \& Pigliaru, F. (2011). Tourism and Development: A recent phenomenon built on old (institutional) roots? WORLD ECONOMY, 34(3), 444-472. https://doi. org/10.1111/j.1467-9701.2010.01320.x

Brown, J., Stadelmann, M., Wang, D., Boni, L., Jachnik, R., \& Kato, T. (2015). Estimating mobilized private finance for adaptation: Exploring data and methods. Climate Policy Initiative (CPI).

Bryman, A. (2012). Social research methods (4th ed). Oxford; New York: Oxford University Press.

Buchner, B., Herve-Mignucci, M., Trabacchi, C., Wilkinson, J., Stadelmann, M., Boyd, R., ... Micale, V. (2013). Global
Landscape of Climate Finance 2013. San Francisco: Climate Policy Initiative. Retrieved from http://climatepolicyinitiative. org/wp-content/uploads/2013/10/The-Global-Landscape-ofClimate-Finance-2013.pdf

Buchner, B., Trabacchi, C., Mazza, F., Abramskiehn, D., \& Wang, D. (2015). Global Landscape of Climate Finance 2015. San Francisco: Climate Policy Initiative.

Caribbean Catastrophe Risk Insurance Facility. (2014). About us. Retrieved 18 July 2014, from http://www.ccrif.org/ content/about-us

Chambwera, M., Njewa, E. D., \& Loga, D. (n.d.). The International Air Passenger Adaptation Levy: Opportunity or risk for Least Developed Countries? (LDC paper series). International Institute for Environment and Development and European Capacity Building Initiative.

Charara, N., Cashman, A., Bonnell, R., \& Gehr, R. (2011). Water use efficiency in the hotel sector of Barbados. Journal of Sustainable Tourism, 19(2), 231-245. https://doi.org/10.1080/ 09669582.2010.502577

Christiansen, L., Ray, A. D., Smith, J. B., \& Haites, E. (2012). Accessing international funding for climate change adaptation: a guidebook for developing countries. Rosklide: UNEP Risø Centre on Energy, Climate and Sustainable Development.

Central Intelligence Agency. (2014). The World Factbook: AustraliaOceania: Palau. Retrieved 23 June 2014, from https://www.cia. gov/library/publications/the-world-factbook/geos/ps.html

Connell, J. (2013). Islands at risk?: environments, economies and contemporary change. Cheltenham: Edward Elgar.

Croes, R. R. (2006). A paradigm shift to a new strategy for small island economies: Embracing demand side economics for value enhancement and long term economic stability. Tourism Management, 27(3), 453-465. https://doi.org/10.1016/j. tourman.2004.12.003

Dzebo, A., \& Pauw, P. (2014). It's time to look beyond the UN's \$100bn climate finance target. Retrieved 19 May 2014, from http://www.rtcc.org/2014/05/01/its-time-to-look-beyond-theuns-100nn-climate-finance-target/

Freeman, R. E. (1984). Strategic management: a Stakeholder Approach. Boston: Pitman.

Gaillard, J. (2007). Resilience of traditional societies in facing natural hazards. Disaster Prevention and Management: An International Journal, 16(4), 522-544. https://doi. org/10.1108/09653560710817011

Garcia, C., \& Servera, J. (2003). Impacts of Tourism Development on Water Demand and Beach Degradation on the Island of 
Mallorca (Spain). Geografiska Annaler, Series A: Physical Geography, 85(3-4), 287-300. https://doi.org/10.1111/j.04353676.2003.00206.x

Gössling, S., Bredberg, M., Randow, A., Sandstrom, E., \& Svensson, P. (2006). Tourist Perceptions of Climate Change: A Study of International Tourists in Zanzibar. Current Issues in Tourism, 9(4), 419-435. https://doi.org/10.2167/cit265.0

Gössling, S., Peeters, P., Hall, C. M., Ceron, J.-P., Dubois, G., Lehmann, L. V., \& Scott, D. (2012). Tourism and water use: Supply, demand, and security. An international review. Tourism Management, 33(1), 1-15. https://doi.org/10.1016/j. tourman.2011.03.015

Graci, S., \& Dodds, R. (2010). Sustainable tourism in island destinations. London; Washington, DC: Earthscan.

Gray, B. (1991). Collaborative Alliances: Moving from Practice to Theory. The Journal of Applied Behavioral Science, 27(1), 3-22. https://doi.org/10.1177/0021886391271001

Grimsey, D., \& Lewis, M. (2004). Public private partnerships the worldwide revolution in infrastructure provision and project finance. Cheltenham; Northampton, MA: Edward Elgar. Retrieved from http://search.ebscohost.com/login.aspx?direct $=$ true $\&$ scope $=$ site $\& d b=$ nlebk $\& d b=$ nlabk $\& A N=128391$

Haigh, N., \& Griffiths, A. (2009). The natural environment as a primary stakeholder: the case of climate change. Business Strategy and the Environment, 18(6), 347-359. https://doi. org/10.1002/bse.602

Hall, C. M. (2010). Crisis events in tourism: subjects of crisis in tourism. Current Issues in Tourism, 13(5), 401-417. https:// doi.org/10.1080/13683500.2010.491900

Hall, C. M., \& Härkönen, T. (2006). Lake Tourism: An Integrated Approach to Lacustrine Tourism Systems. Channel View Publications.

Hall, C. M., \& Stoffels, M. (2006). Lake Tourism in New Zealand: Sustainable Management Issues. In C. M. Hall \& T. Härkönen (Eds.), Lake Tourism: An Integrated Approach to Lacustrine Tourism Systems. Channel View Publications.

Hess, J. S., Pauw, P., \& Papyrakis, E. (2015). Can the tourism industry contribute to international adaptation finance? (Briefing Paper No. 2/2015). Bonn: German Development Institute (GDI-DIE). Retrieved from http://www.die-gdi.de/ briefing-paper/article/can-the-tourism-industry-contribute-tointernational-adaptation-finance/

Hodge, G. A. (2004). The risky business of publicprivate partnerships. Australian Journal of Public Administration, 63(4), 37-49. https://doi.org/10.1111/j.14678500.2004.00400.x
Hodge, G. A., \& Greve, C. (2007). Public-Private Partnerships: An International Performance Review. Public Administration Review, 67(3), 545-558. https://doi.org/10.1111/j.15406210.2007.00736.x

Huxham, C., \& Vangen, S. (2002). In S. P. Osborne (Ed.), Public Management: Critical Perspectives (pp. 273-292). Taylor \& Francis.

Intergovernmental Panel on Climate Change. (2014a). Summary for Policymakers. In Climate Change 2014: Working Group II Contribution to the IPCC Fifth Assessment Report. Cambridge: Cambridge University Press. Retrieved from http://ipcc-wg2.gov/ AR5/images/uploads/IPCC_WG2AR5_SPM_Approved.pdf

Intergovernmental Panel on Climate Change. (2014b). Synthesis Report. Contribution of Working Groups I, II and III to the Fifth Assessment Report of the Intergovernmental Panel on Climate Change [Core Writing Team, R.K. Pachauri and L.A. Meyer (eds.)] (p. 151). Geneva: International Pannel on Climate Change.

Juhasz, A., Ho, E., Bender, E., \& Fong, P. (2010). Does use of tropical beaches by tourists and island residents result in damage to fringing coral reefs? A case study in Moorea French Polynesia. Marine Pollution Bulletin, 60(12), 2251-2256. https://doi.org/10.1016/j.marpolbul.2010.08.011

Kolk, A., \& Pinkse, J. (2005). Business Responses to Climate Change: Identifying Emergent Strategies. California Management Review, 47(3), 6-20. https://doi. org/10.2307/41166304

Lewis, J. (1999). Development in disaster-prone places: studies of vulnerability. London: Intermediate Technology.

Liamputtong, P. (2013). Qualitative research methods (Fourth edition). Australia: Oxford University Press.

Mahon, R., Becken, S., \& Rennie, H. G. (2013). Evaluating the business case for investment in the resilience of the tourism sector of small island developing states. Christchurch: Lincoln University (Canterbury N.Z.); Lincoln University. Retrieved from http://researcharchive.lincoln.ac.nz/dspace/ bitstream/10182/5300/3/LEaP_rr_32.pdf

Mansfeld, Y., \& Korman, T. (2015). Between war and peace: conflict heritage tourism along three Israeli border areas. Tourism Geographies, 17(3), 437-460. https://doi.org/10.108 0/14616688.2015.1036916

Méheux, K., \& Parker, E. (2006). Tourist Sector Perceptions of the Natural Hazards in a Small Island Developing State: A Prliminary Study and Recommendations for an Awareness Strategy in Vanuatu. Macquire University. Retrieved from http://www.grif.umontreal.ca/pages/papers2004/Paper $\% 20$ -\%20Meheux\%20K,\%20Parker\%20E.pdf 
Munich Climate Insurance Initiative. (2014). MCII - Mission \& Targets. Retrieved 16 July 2014, from http://www.climateinsurance.org/front_content.php?idcat $=876$

Müller, B. (2008). International Air Passenger Adaptation Levy (IAPAL): A proposal by the Group of Least Developed Countries (LDCs) within the framework of the Bali Action Plan (Policy Brief). Oxford: European Capacity Building Initiative.

Narayan, P. K., Narayan, S., Prasad, A., \& Prasad, B. C. (2010). Tourism and economic growth: a panel data analysis for Pacific Island countries. Tourism Economics, 16(1), 169-183. https:// doi.org/10.5367/000000010790872006

Nurse, L. A., McLean, R. F., Agard, J., Bringuglio, L. P., DuvatMagnan, V., Pelesikoti, N., ... Webb, A. (2014). Small islands. In: Climate Change 2014: Impacts, Adaptation, and Vulnerability. In V. R. Barros, C. B. Field, D. J. Dokken, K. J. Mastrandrea, T. E. Mach, M. Bilir, ... L. L. White (Eds.), Part B: Regional Aspects. Contribution of Working Group II to the Fifth Assessment Report of the Intergovernmental Panel on Climate Change (pp. 1613-1654). Cambridge: Cambridge University Press.

Orts, E. W., \& Strudler, A. (2002). The Ethical and Environmental Limits of Stakeholder Theory. Business Ethics Quarterly, 12(2), 215-233. https://doi.org/10.2307/3857811

Osborne, S., \& Murray, V. (2000). Understanding the process of public-priavte partnerships. In S. Osborne (Ed.), PublicPrivate Partnerships: Theory and Practice in International Perspective (pp. 70-83).

Osorio, S. G., \& Best, G. (2015). A Case Study on Culture Brokers and Their Role in Tourism Management in the Indigenous Community of Taquile Island in Puno, Peru: Role of Culture Brokers in the Indigenous Community of Taquile in Peru. International Journal of Tourism Research, 17(4), 347-355. https://doi.org/10.1002/jtr.1992

Pathak, R. D., Naz, R., Rahman, M. H., Smith, R. F. I., \& Nayan Agarwal, K. (2009). E-Governance to Cut Corruption in Public Service Delivery: A Case Study of Fiji. International Journal of Public Administration, 32(5), 415-437. https://doi. org/10.1080/01900690902799482

Pauw, P., \& Pegels, A. (2013). Private sector engagement in climate change adaptation in least developed countries: an exploration. Climate and Development, 5(4), 257-267. https://doi.org/10.1 080/17565529.2013.826130

Pauw, P., \& Scholz, I. (2012). Finanzierung der Klimaanpassung in armen Ländern - Sache des Privatsektors?: Deutsches Institut für Entwicklungspolitik (No. Die aktuelle Kollumne vom 26.11.2012). Bonn: German Development Institute (GDIDIE). Retrieved from http://www.die-gdi.de/die-aktuelle- kolumne/article/finanzierung-der-klimaanpassung-in-armenlaendern-sache-des-privatsektors/

Pauw, W. P. (2015). Not a panacea: private-sector engagement in adaptation and adaptation finance in developing countries. Climate Policy, 15(5), 583-603. https://doi.org/10.1080/1469 3062.2014 .953906

Pauw, W. P., Klein, R. J. T., Vellinga, P., \& Biermann, F. (2016). Private finance for adaptation: do private realities meet public ambitions? Climatic Change, 134(4), 489-503. https://doi. org/10.1007/s10584-015-1539-3

Persson, Å., Klein, R. J. T., Siebert, C., Atteridge, A., Müller, B., Hoffmaister, J., ... Takama, T. (2009). Adaptation finance under a Copenhagen agreed outcome. Stockholm: Stockholm Environment Institute.

Phillips, R.A., \& Reichart, J.(2000). TheEnvironmentasa Stakeholder? A Fairness-Based Approach. Journal of Business Ethics, 23(2), 185-197. https://doi.org/10.1023/A:1006041929249

Phillips, R., Freeman, R. E., \& Wicks, A. C. (2003). What Stakeholder Theory is Not. Business Ethics Quarterly, 13(4), 479-502. https://doi.org/10.5840/beq200313434

Qiu, Z., \& Prato, T. (2012). Economic feasibility of adapting crop enterprises to future climate change: a case study of flexible scheduling and irrigation for representative farms in Flathead Valley, Montana, USA. Mitigation and Adaptation Strategies for Global Change, 17(3), 223-242. https://doi.org/10.1007/ s11027-011-9322-x

Roehrich, J. K., Lewis, M. A., \& George, G. (2014). Are publicprivate partnerships a healthy option? A systematic literature review. Social Science \& Medicine, 113, 110-119. https://doi. org/10.1016/j.socscimed.2014.03.037

Rosenau, P. V. (2000). Public-private policy partnerships. Cambridge, Mass: MIT Press.

Sanger, T., \& Crawley, C. (2009). The Problem with Public-Private Partnerships: Economic crisis exposes the high costs and risks of P3s. Retrieved from https://www.policyalternatives.ca/ publications/monitor/problem-public-private-partnerships

Schelling, T. C. (2007). Climate change: The uncertainties, the certainties and what they imply about action. The Economists' Voice 4.3. Colombia University Press. Retrieved from http:// www.degruyter.com/dg/viewarticle.fullcontentlink:pdfeve ntlink/\$002fj\$002fev.2007.4.3\$002fev.2007.4.3.1276\$002f ev.2007.4.3.1276.pdf?t:ac=j\$002fev.2007.4.3\$002fev.2007.4. 3.1276\$002fev.2007.4.3.1276.xml

Scheyvens, R., \& Momsen, J. H. (2008). Tourism and Poverty Reduction: Issues for Small Island States. Tourism Geographies, 10(1), 22-41. https://doi.org/10.1080/14616680701825115 
Scott, D., \& Becken, S. (2010). Adapting to climate change and climate policy: progress, problems and potentials. Journal of Sustainable Tourism, 18(3), 283-295. https://doi. org/10.1080/09669581003668540

Scott, D., Gössling, S., \& Hall, C. M. (2012). International tourism and climate change. Wiley Interdisciplinary Reviews: Climate Change, 3(3), 213-232. https://doi.org/10.1002/wcc.165

Scott, D., Hall, C. M., \& Gössling, S. (2016). A report on the Paris Climate Change Agreement and its implications for tourism: why we will always have Paris. Journal of Sustainable Tourism, 24(7), 933-948. https://doi.org/10.1080/09669582.2016.1187623

Shakeela, A., \& Becken, S. (2015). Understanding tourism leaders' perceptions of risks from climate change: an assessment of policy-making processes in the Maldives using the social amplification of risk framework (SARF). Journal of Sustainable Tourism, 23(1), 65-84. https://doi.org/10.1080/09 669582.2014 .918135

Sovacool, B. K. (2012). Perceptions of climate change risks and resilient island planning in the Maldives. Mitigation and Adaptation Strategies for Global Change, 17(7), 731-752. https://doi.org/10.1007/s11027-011-9341-7

Sovacool, B. K., Linnér, B.-O., \& Klein, R. J. T. (2017). Climate change adaptation and the Least Developed Countries Fund (LDCF): Qualitative insights from policy implementation in the Asia-Pacific. Climatic Change, 140(2), 209-226. https:// doi.org/10.1007/s10584-016-1839-2

Spence, R. (2004). Risk and regulation: can improved government action reduce the impacts of natural disasters? Building Research \& Information, 32(5), 391-402. https://doi. org/10.1080/0961321042000221043

Starik, M. (1995). Should trees have managerial standing? Toward stakeholder status for non-human nature. Journal of Business Ethics, 14(3), 207-217. https://doi.org/10.1007/BF00881435

Surminski, S. (2013). Private-sector adaptation to climate risk. Nature Climate Change, 3(11), 943-945. https://doi. org/10.1038/nclimate2040

Transparency International. (2016). Corruption Perceptions Index 2015. Retrieved 10 November 2016, from http://www. transparency.org/cpi2015\#results-table

Turton, S., Dickson, T., Hadwen, W., Jorgensen, B., Pham, T., Simmons, D., ... Wilson, R. (2010). Developing an approach for tourism climate change assessment: evidence from four contrasting Australian case studies. Journal of Sustainable Tourism, 18(3), 429-447. https://doi. org/10.1080/09669581003639814

United Nations Environmental Programme. (2016). The
Adaptation Finance Gap Report 2016. Nairobi: United Nations Environment Programme (UNEP).

United Nations Educational, Scientific and Cultural Organization. (2012). Knowledge Base: The United Nations World Water Development Report 4 (World Water Development Report No. 4). Paris: United Nations Educational, Scientific and Cultural Organization.

United Nations Framework Convention on Climate Change. (2007). Vulnerability and Adaptation to Climate Change in Small Island Developing States (Background paper for the expert meeting on adaptation for small island developing states). Bonn: United Nations Framework Convention on Climate Change.

United Nations Framework Convention on Climate Change. (2012). Slow onset events (No. Technical Paper). Bonn: United Nations Framework Convention on Climate Change. Retrieved from http://unfccc.int/resource/docs/2012/tp/07.pdf

United Nations Framework Convention on Climate Change. (2014). Private Sector Initiative Actions on Aaptation: Improving customer confidence in attractiveness of destination. Retrieved 12 December 2016, from http://unfccc. int/files/adaptation/nairobi_work_programme/private_sector_ initiative/application/pdf/apple_vacations_et_at.pdf

United Nations Framework Convention on Climate Change. (2015). Paris agreement. UNFCCC. Retrieved from http:// unfccc.int/resource/docs/2015/cop21/eng/109r01.pdf

United Nations Framework Convention on Climate Change. (2016). Private Sector Initiative (PSI) - database of actions on adaptation. Retrieved 12 December 2016, from http:// unfccc.int/adaptation/workstreams/nairobi_work_programme/ items/4623.php

United Nations World Tourism Organization. (2012). Challenges and Opportunities for Tourism Development in Small Island Developing States. Madrid: United Nations World Tourism Organization.

United Nations World Tourism Organization. (2015). Affiliate Members Global Reports, Volume eleven - Public-Private Partnerships: Tourism Development. Madrid: World Tourism Organization (UNWTO).

United Nations World Tourism Organization. (2016). UNWTO annual report 2015. Madrid: United Nations World Tourism Organization.

United Nations World Tourism Organization, United Nations Environmental Programme, \& World Meteorological Organization. (2008). Climate change and tourism: responding to global challenges. Madrid; Paris: World Tourism Organization; United Nations Environment 
Programme ; World Metereological Organization.

van der Velde, M., Green, S. R., Vanclooster, M., \& Clothier, B. E. (2007). Sustainable development in small island developing states: Agricultural intensification, economic development, and freshwater resources management on the coral atoll of Tongatapu. Ecological Economics, 61(2-3), 456-468. https:// doi.org/10.1016/j.ecolecon.2006.03.017

Warner, K., Yuza, K., Zissener, M., Gille, M., Voss, J., \& Wanczeck. (2013). Innovative Insurance Solutions for Climate Change: How to integrate climate risk insurance into a comprehensive climate risk management approach. Bonn: United Nations Univeristy Institute for Environment and Human Security (UNU-EHS).

Wong, E. P. Y., de Lacy, T., \& Jiang, M. (2012). Climate change adaptation in tourism in the South Pacific - Potential contribution of public-private partnerships. Tourism Management Perspectives, 4, 136-144. https://doi. org/10.1016/j.tmp.2012.08.001

Wright, N. (2013). Small Island Developing Stats, disaster risk management, disaster risk reduction, climate change adaptation and tourism (Background Paper prepared for the Global Assessment Report on Disaster Risk Reduction 2013). Geneva: United Nations Office for Disaster Risk Reduction.

World Travel and Tourism Council. (2016a). Travel \& Tourism: Economic Impact 2016: Fiji. London: The World Travel and Tourism Council. Retrieved from http://www.wttc.org/-/media/ files/reports/economic-impact-research/countries-2016/ fiji2016.pdf

World Travel and Tourism Council. (2016b). Travel \& Tourism: Economic Impact 2016: Vanuatu. London: The World Travel and Tourism Council. Retrieved from https://www.wttc. org/-/media/files/reports/economic\%20impact\%20research/ countries\%202015/vanuatu2015.pdf 